\title{
Antioxidant and Chemoprevention Activity of Camelia Sinensis-Annona muricata Extract Combination against WiDr Cells Line
}

Aktivitas Antioksidan dan Kemoprevensi Kombinasi Ekstrak Camelia sisnensis-Annona muricata pada Sel WiDr

\author{
Nazariah Putri ${ }^{1}$, Iwan Dewanto ${ }^{2}$, Rifki Febriansah ${ }^{1 *}$ \\ ${ }^{1}$ School of Pharmacy, Faculty of Medicine and Health Sciences, Universitas Muhammadiyah Yogyakarta \\ ${ }^{2}$ School of Dentistry, Faculty of Medicine and Health Sciences, Universitas Muhammadiyah Yogyakarta
}

DATA OF ARTICLE:

Received: 16 Feb 2021

Reviewed: 08 April 2021

Revised: 10 June 2021

Accepted: 09 July 2021

*CORRESPONDENCE:

rifki.febriansah@umy.ac.id

DOI:

10.18196/mmjkk.v21i2.11158

TYPE OF ARTICLE:

Research
Abstract: Antioxidant compounds have an essential role in inhibiting the process of cell proliferation and have a chemopreventive effect. This study aims to trace the presence of antioxidant compounds allegedly contained in tea leaves (Camelia Sinensis L.) and soursop leaves (Anonna muricata L.) and investigate their potency as chemopreventive agents. Research steps include (1) identify the active compounds using thin-layer chromatography (TLC); (2) find out the potential compounds against cancer cells by molecular docking using Autodock Vina; (3) conduct a potential antioxidant test using free radicals DPPH (1,1-diphenyl-2-pikrihidrazil); and (4) identify the cytotoxic effect on WiDr colon cancer cells test using MTT Assay method. The results showed that the ethanolic extract of Camellia sinensis-Annona muricata leaf combination was suspected of containing flavonoid compounds with $\mathrm{Rf}$ values of 0.66 and 0.68 . Besides, the $\mathrm{DPPH}$ antioxidant test showed an $\mathrm{IC}_{50}$ value of $26.9 \mu \mathrm{g} / \mathrm{mL}$. Cytotoxic potential against WiDr cells resulted in an $\mathrm{IC}_{50}$ value of $41 \mu \mathrm{g} / \mathrm{mL}$. Furthermore, the molecular docking test of epigallocatechin gallate (EGCG) and Acetogenin compounds against bcl-xl target proteins showed the docking score of $-8.1 \mathrm{kcal} / \mathrm{mol}$ and $-6.7 \mathrm{kcal} / \mathrm{mol}$, respectively. It concluded that the extract combination of Camelia Sinensis-Annona muricata leaf had strong potency as an antioxidant and chemopreventive agent against the WiDr colon cancer cells line.

Keywords: Annona muricata L; antioxidants; cytotoxic; Camelia Sinensis L; WiDr cell

Abstrak: Senyawa antioksidan memiliki peranan penting dalam menghambat proses terjadinya proliferasi sel dan memiliki efek kemopreventif. Penelitian ini bertujuan untuk menelusuri senyawa antioksidan yang terkandung pada daun teh (Camelia sinensis L.) dan daun sirsak (Anonna muricata L.) dan potensinya sebagai agen kemopreventif. Langkahlangkah penelitian: (1) mengidentifikasi senyawa antioksidan menggunakan metode KLT; (2) menemukan potensi senyawa antikanker sel kanker kolon, dengan penambatan molekul menggunakan Autodock Vina; (3) menguji potensi antioksidan menggunakan radikal bebas DPPH (1,1-diphenyl-2-pikrihidrazil); dan (4) mengkaji efek sitotoksik pada sel kanker kolon dengan metode MTT Assay. Hasil penelitian menunjukkan bahwa kombinasi ekstrak etanol daun Camelia sinensis L.-Anonna muricata L. mengandung senyawa flavonoid dengan nilai Rf sebesar 0,66 dan 0,68. Hasil uji antioksidan DPPH, menunjukkan nilai IC50 sebesar 26,9 $\mu \mathrm{g} / \mathrm{mL}$. Potensi sitotoksik terhadap sel kanker kolon WiDr menunjukkan nilai $\mathrm{IC}_{50}$ sebesar $41 \mu \mathrm{g} / \mathrm{mL}$. Pada uji penambatan molekuler terhadap senyawa EGCG dan Acetogenin pada protein target bcl-xl diperoleh hasil nilai skor docking berturut-turut sebesar -8,1 dan -6,7 kkal/mol. Disimpulkan bahwa kombinasi ekstrak daun Camelia sinensis L.-Anonna muricata L. mempunyai aktivitas antioksidan yang tinggi dan sitotoksik yang kuat terhadap sel kanker kolon WiDr.

Kata Kunci: Camelia sinensis L; Annona muricata L; antioksidan; sitotoksik; sel WiDr 


\section{INTRODUCTION}

Cancer ranks 2nd after cardiovascular disease. It is estimated that cancer-induced deaths by 2030 will be as many as 12 million people and will continue to increase annually. ${ }^{1}$ In a more specific case, colon cancer in Indonesia ranks 3 with a total case of $15.9 \%$ and caused mortality with a total of $10.8 \%$ in $2012 .{ }^{2}$ In normal cells, there is a suppressor gene serving as control of cell growth. If cell growth occurs, the gene will be activated, leading to a harmonious balance. ${ }^{3}$ However, cancer causes cells to have abnormal growing abilities. It comes from organ cells or body cells that have the ability to inhibit cell growth. ${ }^{4}$

Many factors cause the cell to develop abnormally, one of which is the presence of free radical compounds in the body. The compound is highly reactive and has one free electron that looks for a partner by bonding with electrons nearby and causes the cell to break down. ${ }^{5}$ Meanwhile, antioxidant compounds have an essential role in preventing the adverse effects of free radical compounds in the body. Antioxidants can come from natural and synthetic sources.

Tea leaves (Camellia sinensis L.) have many benefits, including anticancer, antioxidant, antibacterial, etc. ${ }^{6}$ The leaves contain active compounds, including polyphenols, caffeine, and theobromine compounds. ${ }^{7}$ Epigallocatechin gallate (EGCG) is the primary polyphenol found in tea leaves that is effective as an antioxidant and has a bitter taste. Polyphenols on tea leaves are considered to suppress the proliferation of cancer cells and have a chemopreventive effect. Meanwhile, soursop leaves (Annona muricata L.) contain compounds including tannins, phytosterols, calcium oxalate, alkaloids, flavonoids, and acetogenin. ${ }^{8}$ The purpose of this study was to find out the potential combination of ethanol extract of tea leaves and soursop leaves, antioxidant activity in both combinations of plants in warding off free radicals, knowing the potential of EGCG and Acetogenin compounds with molecular docking analysis on bcl-xl proteins, and knowing cytotoxic ability against WiDr colon cancer cells.

\section{MATERIALS AND METHOD}

\section{Sample and Extract Preparation}

Tea leaf simplisia powder (Camellia sinensis L.) was obtained from Tawamangu, while soursop leaves (Annona muricata L. ) were obtained from the Bantul district. Tea leaves and fresh soursop leaves were washed clean with running water and then dried in the sun by covered using a black cloth. The drying process was done for 10 days or until the tea leaves and soursop leaves were brittle. It was then blended until smooth and sifted until it became simplisia powder. Each pollen of simplisia leaf tea and soursop leaf was weighed as much as 500 grams of extracted by maceration method using solvent ethanol $70 \%$, soaked for 5 days with the stirring process every day. Re-maceration was conducted and soaked for 2 days which would then be retrieved to extract liquid. The following process was evaporation using a rotary evaporator with a temperature between $40-50^{\circ} \mathrm{C}$.

\section{Analysis of Flavonoid Compounds with TLC Method}

To identify the content of flavonoids or polyphenols in tea leaf extract and soursop leaves, it used the phase of motion that was n-Butanol: Acetic Acid: Water (BAW) in a ratio of 7:2:1. Meanwhile, the stationary phase used was silica gel GF254. Once in the exclusion, the TLC plate was removed from the chamber and was dried in the oven temperature of $60^{\circ} \mathrm{C}$ for 10 minutes. The plate was later observed under a UV lamp with a wavelength of $254 \mathrm{~nm}$ to identify the results (Rf value). After that, in identifying a color reaction, ammonia vapor was vapor to detect the presence of flavonoids.

\section{Antioxidant Activity Test with DPPH Method}

1. Production of raw DPPH solution

A number of $15.8 \mathrm{mg}$ powder DPPH was already weighed, then was measured out with methanol with as much as $100 \mathrm{~mL}$ of the solution. It was then obtained a DPPH concentration of $0.4 \mathrm{mM}$. Furthermore, the solution was mixed for 30 seconds then wrapped using aluminum foil.

2. The production of the samples solution $20 \mathrm{mg}$ of ethanolic extracts of tea leaves and soursop leaves were dissolved in $20 \mathrm{ml}$ methanol. The concentration of the sample solution obtained was $1000 \mu \mathrm{g} / \mathrm{mL}$. Next, 5 levels of concentration of 7.5; $10 ; 15 ; 20$, and $30 \mu \mathrm{g} / \mathrm{mL}$ were created.

3. Making a solution of Rutin Compound 
Rutin analysis of $5 \mathrm{mg}$ was inserted into the $50 \mathrm{~mL}$ measuring flask and then reconstituted using methanol to mark boundaries. Next parent solution made the series levels of concentration that were $0.5 ; 1 ; 5 ; 10 ; 20$ and $30 \mu \mathrm{g} / \mathrm{mL}$.

4. determination of operating time

The rutin concentrations of $3 ; 4$ and $5 \mu \mathrm{g} / \mathrm{mL}$ by as much as $1 \mathrm{~mL}$ were put into a $5 \mathrm{ml}$ measuring flask. DPPH solution was then added as much as $1 \mathrm{~mL}$ into each pumpkin measure, subsequently added methanol to mark boundaries. Each solution was moved into test tubes and then did the vortex for 30 seconds. The absorbance of the solution was read at $\lambda 514 \mathrm{~nm}$ every 5 minutes during the last 45 minutes. Replication was done 3 times.

5. maximum Wavelength Assignment

As many as $1 \mathrm{~mL}$ solutions of DPPH were put into a $10 \mathrm{ml}$ measuring flask, and methanol was added to mark boundaries. The solution was then moved into test tubes, vortex for 30 seconds. The operating time was set, and the absorption was observed at a wavelength of $200-800 \mathrm{~nm}$.

6. Measurement of absorbance of DPPH solution

As much as $2 \mathrm{~mL}$ solution of DPPH was put into a $10 \mathrm{~mL}$ measuring flask, and methanol was added to mark boundaries. The operating time was then set. The absorption was read at $\lambda$ maximum, performed replication as much as 3 times.

7. Measurement of the absorbance of the sample solution and rutin

The $2 \mathrm{~mL}$ measuring flask of DPPH solution measured a $10 \mathrm{~mL}$ sample solution, then the rutin of $2 \mathrm{~mL}$ concentration on the series have been made. Next, methanol was then added to mark boundaries in vortex solution for 30 seconds during the operating time. The absorbance of the solution was later observed at $\lambda$ maximum, and the replication was performed 3 times.

The sample of absorbance data in the form of the antioxidant formula using percent:

$$
\% \text { Inhibition }=\frac{\text { absorbance blank }- \text { sample absorbance }}{100 \% \text { absorbance }} \times 100 \%
$$

The calculation of the IC50 can be carried out by inserting the value of 50 as a linear regression equation of $y . x$ is a relationship, and $y$ is \% of antioxidants.

\section{Molecular Docking test}

1. Preparation of protein

The target of proteins was sought from PDB (Protein Data Bank) and GDP to bcl-xl: 1YSG as the target in the form of active protein that will bind to the native ligand. The native ligand was then removed by the YASARA process to provide space (pocket/cavity). This space was later used in the analysis of the interaction of ligand and protein.

2. Preparation of the test compound EGCG and Acetogenin

Optimization of the structure of the test compound was carried out using the Marvin Sketch Program. The 3D structure of EGCG and Acetogenin was fully drawn with a hydrogen atom, then optimization of conformation was carried out.

3. Validation of molecular docking method Native ligand reattached to proteins that have been removed is native ligand using the Autodock Vina program. The difference in coordination between the two ligands was seen from the RMSD value (root mean square distance). If the RSMD value is $<2.0$ amstrom (A), the protocol is accepted, and the test compound's docking process on the target protein can be carried out. In contrast, if the RSMD value is > 2.0 A, another protein with code (GDP ID) is used.

4. Docking EGCG and Acetogenin on protein targets

The test compound of EGCG or Acetogenin was already eliminated the native ligand using Autodock Vina. The analysis results showed the compounds with the conformation of the lowest energy that has to bind to a protein target-visualization of the amino acid residues that interact with the ligand using DS Visualizer.

\section{MTT assay}

WiDr cells were planted in a microplate of 96 wells with a density of $5 \times 10^{3}$ cells/well and incubated for 48 hours to obtain good growth. After that, the medium was replaced with a new one with a DMSO cosolvent and incubated at $37^{\circ} \mathrm{C}$ in a $5 \% \mathrm{CO} 2$ incubator for 48 hours. At the end of incubation, the media and extract were discarded then the cells were washed with PBS. In each well, $100 \mu \mathrm{L}$ of cultural media and $10 \mu \mathrm{L}$ MTT of $5 \mathrm{mg} / \mathrm{mL}$ were added. Cells were re-incubated for $4-6$ hours in a $5 \% 37^{\circ} \mathrm{C} \mathrm{CO} 2$ incubator. The MTT 
reaction was stopped with $\mathrm{HCL} 4 \mathrm{~N}$-isopropanol (1:100), rocked on top of the shaker for 10 minutes. Absorption was read with Elisa reader (Benchmark Bio-Rad) at the wavelength of $595 \mathrm{~nm}$.

\section{RESULT}

\section{Extraction Result}

500 grams of tea leaves and 500 grams of soursop leaves obtained liquid extract as much as 2,450 $\mathrm{mL}$ of tea leaves and $2,550 \mathrm{~mL}$ of soursop leaves. The liquid extract was evacuated with a rotary evaporator and obtained 27.3 grams of thick extract of tea leaves and 28.7 grams of thick extract of soursop leaves.

\section{TLC Test Result}

The experiments carried out in the mobile phase resulted in a good comparison which was $n$-butanol: acetic acid:water (7:2:1) compared to other mobile phases. To identify the presence of flavonoid content followed by color testing, the method used was evaporation with ammonia compounds, rutin chromatogram plates, ethanol extract tea leaves, and ethanol extract soursop leaves steamed with ammonia for a few moments until discoloration occurred in the spots (Figure 1). Next, the detection using visible rays and UV rays of $254 \mathrm{~nm}$ produced 2 spots on chromatograms of ethanol extract of tea leaves and 2 spots on chromatograms of soursop leaf ethanol extract, which was also compared to the same rutin standard. The Rf value of each spot can be seen in Table 1.
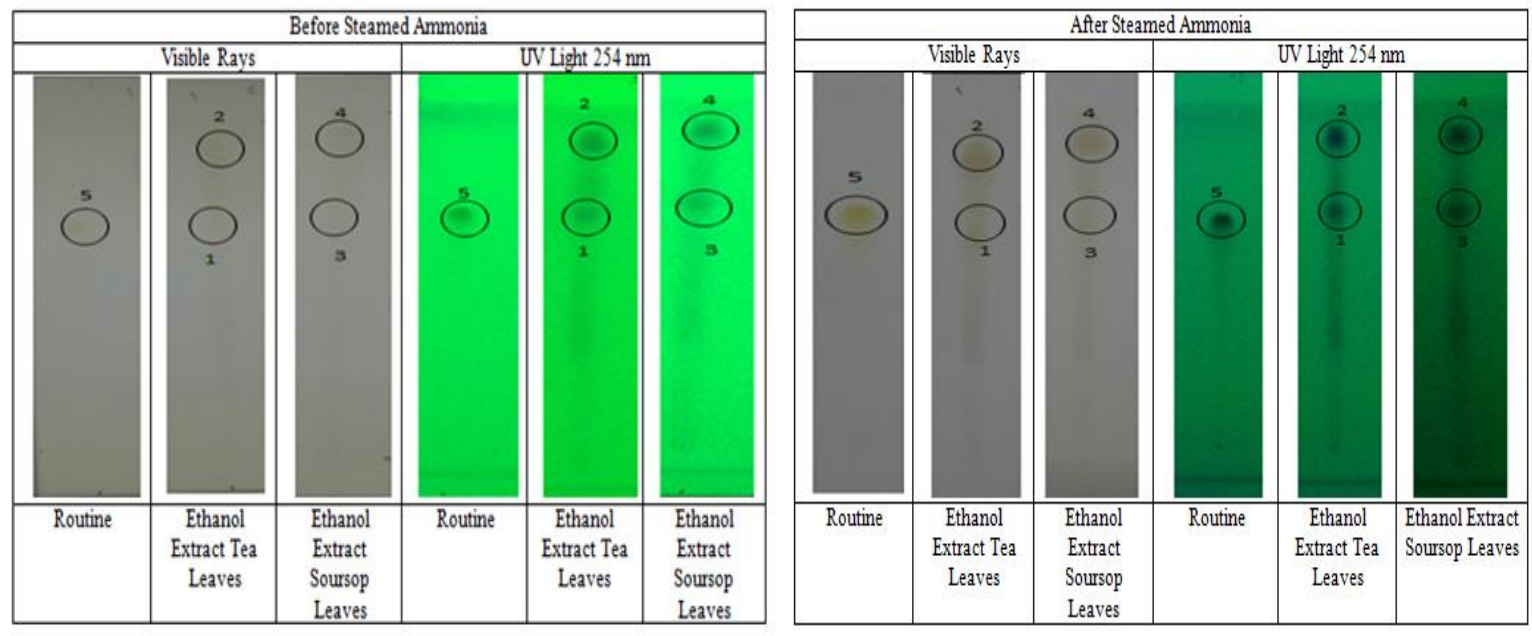

Figure 1. Spots on Chromatograms from TLC Analysis of the Samples and Standard Before and After Evaporated with Ammonia Reagen Detected Under UV $254 \mathrm{~nm}$ and Visible Light

Table 1. Rf Value from TLC Analysis of the Samples and Standard before and after Evaporated with Ammonia Compound Detected Under UV $254 \mathrm{~nm}$ and Visible Light

\begin{tabular}{cccccc}
\hline \multirow{2}{*}{$\begin{array}{c}\text { Spotting } \\
\text { Number }\end{array}$} & \multirow{2}{*}{ Rf } & \multicolumn{2}{c}{ Color Before Ammonia } & \multicolumn{2}{c}{ Color After Ammonia } \\
\cline { 2 - 5 } & & Visible & UV 254 nm & Visible & UV 254 nm \\
\hline 1 & 0.66 & Colorless & Attenuation & Yellow & Darker damping \\
2 & 0.89 & Colorless & Attenuation & Crimson Yellow & Darker damping \\
3 & 0.68 & Colorless & Attenuation & Yellow & Darker damping \\
4 & 0.91 & Colorless & Attenuation & Crimson Yellow & Darker damping \\
5 & 0.66 & Colorless & Attenuation & Yellow & Darker damping \\
\hline
\end{tabular}

The result showed that ethanolic extract of tea leaves and soursop leaves contained flavonoids in both spots. It is evidenced by yellow discoloration after steaming ammonia and blue color (damping) at UV $254 \mathrm{~nm}$ with an $\mathrm{Rf}$ value of 0.66 .

\section{Antioxidant Activity Result with DPPH Method}

The DPPH (1,1-diphenyl-2-pikrihidrazil) suppression method was based on reducing dpph-colored free radical methanol solution due to inhibition of free radicals. When the purple solution of DPPH met the electron donor material, the DPPH would be reduced, causing the purple color to fade to yellow from the pikril group. ${ }^{9}$ 
Based on experiments, the sample levels i.e., 5 series; 7.5; 10; 15; 20; $30 \mu \mathrm{g} / \mathrm{mL}$ were each replicated 3 times. While the series of levels for rutin that is $0.5 ; 1 ; 2 ; 5 ; 10 ; 20 \mu \mathrm{g} / \mathrm{mL}$ was replicated 3 times. Absorbance reading of respective series samples and rutin levels was done at a wavelength of maximum DPPH. Based on the screening results, DPPH's maximum absorption reading using a spectrophotometer was $514 \mathrm{~nm}$. The result of the percentage of the inhibition can be seen in Table 2 .

Table 2. The Average Absorbance of the Rutin Standard Compound (A) and Combination of Ethanol Extracts of Tea Leaves and Soursop Leaves (B)

\begin{tabular}{|c|c|c|c|c|c|c|c|c|c|c|}
\hline \multirow[t]{2}{*}{ No } & \multicolumn{2}{|c|}{$\begin{array}{c}\text { Concentratio } \\
\mathrm{n}(\mu \mathrm{g} / \mathrm{mL})\end{array}$} & \multicolumn{2}{|c|}{$\begin{array}{l}\text { The Average } \\
\text { Absorbance }\end{array}$} & \multicolumn{2}{|c|}{$\begin{array}{c}\text { Standard } \\
\text { Deviation }\end{array}$} & \multicolumn{2}{|c|}{ Absorbance Blank } & \multicolumn{2}{|c|}{ Percent Inhibition (\%) } \\
\hline & $\mathrm{A}$ & $\mathrm{B}$ & A & B & A & B & A & B & $\mathrm{A}$ & B \\
\hline 1 & 0.5 & 5 & 0.641 & 0.661 & 0.026 & 0.016 & 0.7023 & 0.7023 & 8.73 & 5.88 \\
\hline 2 & 1 & 7.5 & 0.638 & 0.598 & 0.006 & 0.022 & 0.7023 & 0.7023 & 9.11 & 14.90 \\
\hline 3 & 2 & 10 & 0.625 & 0.532 & 0.034 & 0.003 & 0.7023 & 0.7023 & 11.01 & 24.30 \\
\hline 4 & 5 & 15 & 0.557 & 0.488 & 0.013 & 0.017 & 0.7023 & 0.7023 & 20.76 & 30.56 \\
\hline 5 & 10 & 20 & 0.402 & 0.476 & 0.021 & 0.061 & 0.7023 & 0.7023 & 42.76 & 32.27 \\
\hline 6 & 20 & 30 & 0.189 & 0.298 & 0.063 & 0.018 & 0.7023 & 0.7023 & 73.04 & 57.53 \\
\hline 7 & 30 & 40 & 0.055 & 0.186 & 0.014 & 0.022 & 0.7023 & 0.7023 & 92.22 & 73.54 \\
\hline
\end{tabular}

Absorbance data above can calculate \% inhibition using the formula control absorbance reduced with further positive results and divided by negative control absorbance. Negative control absorbance was derived from DPPH absorbance readings. The readings of average DPPH absorbance was 0.7023 . The IC50 value was obtained by connecting the percentage of inhibition with concentration and then creating a linear regression. The graph of a linear regression relationship between the percentage of concentration with inhibition rutin and the combination of ethanol extracts of leaves of tea and soursop leaf can be seen in Figure 2.

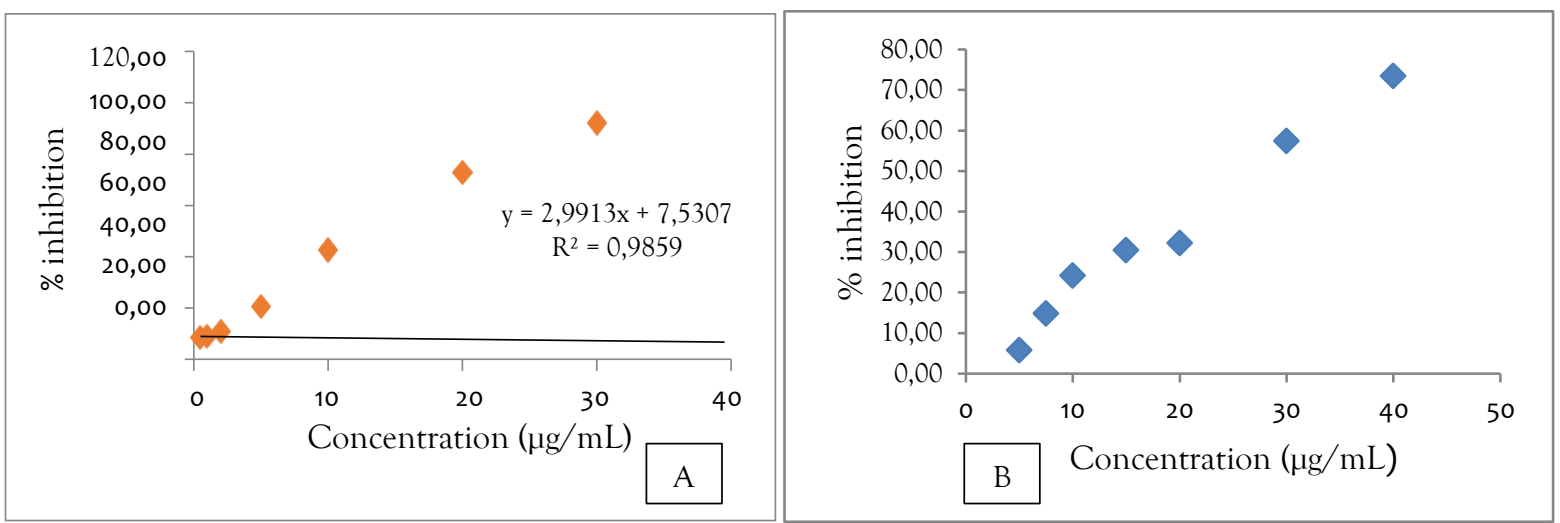

Figure 2. Linear regression of rutin standard (A) and combination of ethanolic extracts of tea and soursop leaves (B)

Linear regression results from the data can be done by modifying the IC 50 value calculations of $y$ being 50. From the calculation result, it was obtained that rutin showed a very strong antioxidant effect with an IC50 value of $14.20 \mu \mathrm{g} / \mathrm{mL}$, while the extract combination of EEDT and EEDS also showed a very strong antioxidant effect with an IC50 value of $26.20 \mu \mathrm{g} / \mathrm{mL}$. According to Mardawati et al, the IC50 value of antioxidants below $50.0 \mu \mathrm{g} / \mathrm{mL}$ was included in the category of very strong effect. ${ }^{10}$

\section{Molecular Docking Result}

Molecular docking is a computational method that aims to mimic the interaction events of a ligand molecule with a target receptor or protein. ${ }^{11}$ Thus, this method can predict the strength of the relationship or the affinity of the bonds between the two molecules. Whether or not a docking is successful is determined by two components: algorithmic search and scoring function. ${ }^{12}$ Molecular docking test aims to find out the interaction of a ligand with the protein molecules of the target upon the in-vitro testing. Molecular docking was used to test applications, i.e., Autodock Vina and some supporting applications such as open babel were used to convert each file as GDP to pdbqt to visualize using other applications. The DS visualization was used to view the structure and form of the interactions between the ligand and the protein molecular basis. The proteins tested in this study were the receptors of bcl-xl, obtained by molecular docking score. The docking 
score is the value of the free energy needed by the ligand for the protein interaction to get smaller. It indicates that it is increasingly easy to interact. RMSD value and Score of the test compounds between docking and protein bcl-xl can be seen in Table 3 .

Table 3. Docking Score of EGCG and Acetogenin Compounds against Protein bcl-xl

\begin{tabular}{ccccc}
\hline Active Compound & Protein & RMSD Value & Docking Score & Conformation \\
\hline Native ligand & & 0.992 & -6.4 & 2 \\
EGCG & BCL-xl & 0.284 & -8.1 & 2 \\
Acetogenin & (PDB ID: & 1.567 & -6.7 & 5 \\
Doxorubicin & 1YSG) & 1.207 & -3.6 & 2 \\
5-Fluorouracil & & 1.439 & -4.9 & 2 \\
\hline
\end{tabular}

\section{MTT Assay Result}

This test was conducted to determine the ability of a compound to inhibit $50 \%$ of cell growth. Cytotoxic activity test in this study was conducted to find out the toxicity of test material that was a combination of ethanol extract of tea leaves and soursop leaves against cancer cells. The cancer cells used in this study were WiDr colon cancer. The sample absorbance, \% of Living Cells, and cytotoxic IC50 value can be seen in Table 4 .

Table 4. Data of Sample of Absorbance, \% of Living Cells and Cytotoxic IC50 Value on WiDr Cells Line after Ethanol Extract Treatment of Tea Leaves and Soursop Leaves

\begin{tabular}{cccc}
\hline $\begin{array}{c}\text { Concentration } \\
\text { Log }\end{array}$ & $\begin{array}{c}\text { Sample of Absorption } \\
\text { Average }\end{array}$ & Living Cells (\%) & $\begin{array}{c}\text { Standard } \\
\text { Deviation }\end{array}$ \\
\hline 37.5 & 0.543 & 0.912 & 0.085 \\
75 & 0.662 & 0.695 & 0.126 \\
112.5 & 0.694 & 0.804 & 0.131 \\
150 & 0.659 & 0.706 & 0.225 \\
Average & Cell control & 0.758 & \\
Absorption & Media & 0.432 & \\
\hline \multirow{3}{*}{ Equation } & $\mathrm{y}=-0.0000 \mathrm{x}+0.864$ & & \\
& $\mathrm{R}^{2}=0.896$ & & \\
& $\mathrm{IC}_{50}=\mathbf{4 1} \mathbf{\mu g} / \mathrm{mL}$ & & \\
\hline
\end{tabular}

\section{DISCUSSION}

Green tea and green tea polyphenols have been shown to have anti-cancer activity in several laboratory studies, which could be mediated through antioxidant or pro-oxidant mechanisms. Green tea polyphenols such as EGCG inhibit cell viability and induce apoptosis in several cancer cell lines such as osteogenic sarcoma ${ }^{13}$, lymphoblastoid cells ${ }^{14}$, leukemia cells $s^{15}$, melanoma cells ${ }^{16}$, T lymphocytes $^{17}$, and larynx carcinoma ${ }^{18}$. EGC can inhibit breast cancer cell viability through induction of apoptosis, yet not in normal breast cells ${ }^{19}$. Apoptosis by green tea polyphenols may occur independently in caspase-3 induction through activation of $\mathrm{p} 53^{18}$. Moreover, evidence for cell cycle modulation also exists. EGCG in green tea causes a reduction in cell viability through $\mathrm{G} 1$ growth arrest in human breast cancer cells ${ }^{20,21}$, which is likely to occur through the suppression of cyclin $\mathrm{D}^{16}$. Green tea polyphenols can even cause differentiation of cancer cells into slower proliferating cells ${ }^{22}$. Based on the identification results using the TLC test, samples of ethanol extract of tea leaves with spots number 1 and 2 that have $\mathrm{Rf} 0.66$ and 0.89 and samples of ethanol extract soursop leaves with spotting numbers 3 and 4 that have $\mathrm{Rf}$ respectively 0.68 and 0.91 were suspected of containing flavonoid compounds. All four spots experienced blue damping at UV $254 \mathrm{~nm}$ and were colorless in visible light before being fed with ammonia. According to the rf comparing value after being infused with ammonia in the light, it appeared dim yellow patches indicating the content of flavonoids, ${ }^{23}$ in the form of glycoside flavonoids in patches 1 and 3, indicating in spot number 5 with a value of $\mathrm{Rf} 0.66$. It aligns with previous research that rutin compound $\mathrm{Rf}$ values ranged between 0.625 and 0.75 with BAW mobile phase and the rutin compound. ${ }^{24}$ Furthermore, quercetin is one of the flavonoid derivatives classified into flavonols and catechins found in tea leaves and soursop leaves included in the flavonol flavonoids group. ${ }^{25}$ Thus, the rutin compound used as a comparison is appropriate to detect the presence of flavonoid content. In spots number 2 and 4, it was not a flavonoid glycoside compound as it had a different and higher Rf value. It was 
suspected that this flavonoid compound was a type of genistein since genistein is a less polar flavonoid. ${ }^{26}$ The Rf values of both samples were almost identical, indicating that the flavonoid compounds found in the ethanol extract sample of tea leaf and soursop leaf ethanol extract had a similar type of compound.

The linear regression equation obtained from the antioxidant test can be calculated IC 50 value. The combination of ethanol extract of Camellia sinensis leaf and Annona muricata L. leaves had an IC50 value of $26.90 \mu \mathrm{g} / \mathrm{mL}$. Besides, the antioxidant activity test result from a combination of ethanol extract of tea leaves and soursop leaves showed that its activity falls into a very strong category as an antioxidant. The ic50 value obtained from the test solution was more significant when compared to the rutin comparison solution that had an IC50 value of $14.20 \mu \mathrm{g} / \mathrm{mL}$. It indicated that rutin as a positive control had higher antioxidant activity when compared to the combination of ethanol extract of tea leaves and soursop leaves.

Furthermore, based on molecular docking tests, docking scores obtained from EGCG compounds were -8.1, and acetogenin was -6.7. Compared to doxorubicin and 5-FU, both compounds had smaller docking scores. The smaller the docking score is, the better the ligand and protein bond will be. In addition, the analysis of EGCG and Acetogenin compounds had a stronger bond than doxorubicin to the target protein BCL-xl.

Based on the cytotoxic result, the IC50 value was $41.375 \mu \mathrm{g} / \mathrm{mL}$. The IC50 value is considered potent if the value is less than $100 \mu \mathrm{g} / \mathrm{mL}$. It indicated that the combination of the tea leaf extract and soursop leaves had very strong potential in killing WiDr cancer cells.

\section{CONCLUSION}

The combination of tea leaf ethanol extract (Camellia sinensis L.) and soursop leaves (Annona muricata L.) was proven to contain flavonoid group compounds and have very strong antioxidant activity with IC50 values of $29.90 \mu \mathrm{g} / \mathrm{mL}$. In in silico molecular docking between acetogenin compound in soursop leaves with bcl-xl protein, it had a strong affinity with a docking score of -6.7. In contrast, the compound EGCG on tea leaf had fairly strong potential with bcl-xl with a docking score of -8.1. Furthermore, the combination of tea leaf and soursop leaves ethanolic extract had strong cytotoxic activity on the WiDr colon cancer cells line with an IC50 value of $41 \mu \mathrm{g} / \mathrm{mL}$.

\section{ACKNOWLEDGEMENT}

We would like to thank LP3M UMY and the Indonesia Ministry of Education and Culture for funding this research.

\section{CONFLICT OF INTEREST}

We stated that there is no conflict of interest between the authors.

\section{REFERENCES}

1. NCI. Cancer Treatment. 2017. Available from: http://www.cancer.gov/cancertopics/treatment.html. 2012. [cited 2017 May 9]

2. IARC. Tumours of the Colon and Rectum. 2012 [cited 2017 May 9]. https://www.iarc.fr/en/publications/pdfsonline/pa.

3. Aziz M, Andrijono, Saifuddin, A B. Buku Acuan Nasional Onkologi Ginekologi. Jakarta: Yayasan Bina Pustaka Sarwono Prawirohardjo. 2006.

4. AS T, AS M. Facing Cancer: a Complete Guide for People with Cancer, Their Families, and Caregivers (CLS Education). In: $1^{\text {st }}$ ed. United States of America; 2004: 2-3.

5. Yuhernita, Juniarti. Analisis Senyawa Metabolit Sekunder dari Ekstrak Metanol Daun Surian yang Berpotensi sebagai Antioksidan. MAKARA Sci Ser. 2011; 15(1): 48-52. https://doi/org/10.7454/mss.v15i1.877

6. Alamansyah A. Taklukkan Penyakit dengan Teh Hijau. Jakarta: Agro Media Pustaka; 2006: 34-36.

7. Fulder S. Khasiat Teh Hijau in $1^{\text {st }}$ ed., Jakarta: Prestasi Pustaka. 2004.

8. Wulan J. Dahsyatnya Khasiat Sirsak untuk Banyak Penyakit yang Mematikan. Yogyakarta: ANDI. 2012.

9. Prayoga E. Perbandingan Efek Ekstrak Daun Sirih Hijau (Piper betle L.) dengan Metode Difusi Disk dan Sumuran terhadap Pertumbuhan Bakteri Staphylococcus aureus. Skripsi. UIN Syarif Hidayatullah. 2013.

10. Mardawati E, Achyar C, Marta H. Kajian Aktivitas Antioksidan Ekstrak Kulit Manggis (Garcinia mangostana L) dalam Rangka Pemanfaatan Limbah Kulit Manggis di Kecamatan Puspahiang Kabupaten Tasikmalaya. Teknotan J Ind Teknol Pertanian. 2008; 2(3).

11. Motiejunas D, Wade RC. Structural, Energetic, and Dynamic Aspects of Ligand-receptor Interactions. Compr 
Med Chem II. 2006; 4:193-214.

12. Mukesh B, Rakesh K. Molecular Docking: A Review. Int J Res Ayurveda Pharm. 2011; 2(6): 1746-1751.

13. Sang JJ, Dong HH, Jeong HK. Inhibition of Proliferation and Induction of Apoptosis by EGCG in Human Osteogenic Sarcoma (HOS) Cells. Arch Pharm Res. 2006; 29(5): 363-368.

14. Noda C, He J, Takano T, Tanaka C, Kondo T, Tohyama K, et al. Induction of apoptosis by epigallocatechin-3gallate in human lymphoblastoid B cells. Biochem Biophys Res Commun. 2007;362(4):951-957. https://doi.org/10.1016/j.bbrc.2007.08.079

15. Nakazato T, Ito K, Miyakawa Y, Kinjo K, Hozumi N, Ikeda Y, et al. Catechin, a green tea component, rapidly induces apoptosis of myeloid leukemic cells via modulation of reactive oxygen species production in vitro and inhibits tumor growth in vivo. Haematologica. 2005;90(3):317-325.

16. Nihal M, Ahmad N, Mukhtar H, Wood GS. Anti-proliferative and proapoptotic effects of (-)-epigallocatechin-3gallate on human melanoma: Possible implications for the chemoprevention of melanoma. Int J Cancer. 2005;114(4):513-521. https://doi.org/10.1002/ijc.20785

17. Li HC, Yashiki S, Sonoda J, Lou H, Ghosh SK, Byrnes JJ, et al. Green tea polyphenols induce apoptosis in vitro in peripheral blood T lymphocytes of adult T-cell leukemia patients. Japanese J Cancer Res. 2000;91(1):34-40 https://doi.org/10.1111/j.1349-7006.2000.tb00857.x

18. Lee JH, Jeong YJ, Lee SW, Kim D, Oh SJ, Lim HS, et al. EGCG Induces Apoptosis in Human Laryngeal Epidermoid Carcinoma Hep2 Cells via Mitochondria with the Release of Apoptosis-inducing Factor and Endonuclease G. Cancer Lett. 2010; 290(1): 68-75. https://doi.org/10.1016/j.canlet.2009.08.027

19. Vergote D, Cren-Olivé C, Chopin V, Toillon RA, Rolando C, Hondermarck H, et al. (-)-Epigallocatechin (EGC) of Green Tea Induces Apoptosis of Human Breast Cancer Cells but not of Their Normal Counterparts. Breast Cancer Res Treat. 2002; 76(3): 195-201. https://doi.org/10.1023/a:1020833410523

20. Kavanagh KT, Hafer LJ, Kim DW, Mann KK, Sherr DH, Rogers AE, et al. Green Tea Extracts Decrease Carcinogen-induced Mammary Tumor Burden in Rats and Rate of Breast Cancer Cell Proliferation in Culture. J Cell Biochem. 2001; 82(3): 387-398. https://doi.org/10.1002/jcb.1164

21. Lin JK, Liang YC, Lin-Shiau SY. Cancer Chemoprevention by Tea Polyphenols through Mitotic Signal Transduction Blockade. Biochem Pharmacol. 1999; 58(6): 911-5.

22. Zhou B, Pan J, Dai F, Zhao C, Zhang L, Wei Q, et al. Redifferentiation of Human Hepatoma Cells Induced by Green Tea Polyphenols. Res Chem Intermed. 2004; 30(6): 627-36.

23. Aminah S, Pramono S. Isolasi Flavonoid Daun Murbei (Morus Alba L.) serta Uji Aktivitasnya sebagai Penurun Tekanan Darah Arteri pada Anjing Teranestesi. Maj Farm. 2017; 9(1): 235-42. https://doi.org/10.22146/farmaseutik.v9i1.24103

24. Suhendi A, Sjahid R, Hanwar D. Isolasi dan Identifikasi Flavonoid dari Daun Dewandaru (Eugenia uniflora L.) Isolation and Identification of Flavonoids from Dewandaru (Eugenia uniflora L.) Leaf. 73 Pharmacon. 2011; 12(2): 73-81. https://doi.org/10.23917/pharmacon.v12i2.36

25. Neldawati, Ratnawulan, Gusned. Analisis Nilai Absorbansi dalam Penentuan Kadar Flavonoid untuk Berbagai Jenis Daun Tanaman Obat. Pillar of Physics,. 2013; 2: 76-83.

26. Andersen O, Markham K. Flavonoids: Chemistry, Biochemistry, and Applications. CRC, Taylor \& Francis, Boca Raton, FL; 2006. 